Spitsyna A. Ye.

Candidate of Pedagogical Sciences, Associate Professor at Department of Economics

National Transport University

\title{
DEVELOPMENT OF ECONOMIC CULTURE IN IMPROVING ENTERPRISE PERFORMANCE IN UKRAINE
}

\section{Summary}

Economic culture is a basic category that reflects not only the quality of social relations during production, distribution and consumption of material goods, but also a measure of social development. It is a set of institutionalized activities that ensure the adaptation of specific societies and groups to the economic conditions of their life. Economic culture is a special area of culture associated with the reproduction of relations between people in the process of and for their economic activities.

Embodying moral, religious and aesthetic values, economic culture forms its own core - the national economic consciousness, which can be either constructive or destructive. Economic culture is made up of economic knowledge, economic thinking and economic orientations.

Under socio-cultural transformations, professional knowledge becomes an important element of economic culture. Today, every technological decision has an economic aspect. Economic culture is the basis of any professional activity because it implies individuals' entrepreneurial and creative qualities, competence, professional skills, and responsibility. Economic and moral cultures share the same goals, i.e., the formation of ideas, attitudes, principles and rules of conduct in line with the universal humanitarian values.

\section{Introduction}

Economic culture is an important component of the economic activity of society. It largely determines the level of economic activity in the country, its economic development and the rate of economic growth. It is impossible to overcome the imbalanced development of the economy during its transformation into a socially oriented sustainable economy without a substantial renewal of the economic culture.

The problem of economic culture is relatively new in economic theory and therefore is poorly investigated both in Ukraine and abroad. Thus, in Ukraine, economic culture has been investigated only since 2000s, while business culture, which is now treated mainly as business etiquette, has been studied even later. The problem of economic culture is becoming even more significant due to the growing role of professionals as subjects of economic behavior. 
Economic values are generally accepted ideas about the goals that an individual strives for in economic activity. They function in the form of an ideal, the basic principles of thinking and are perfect criteria for assessing economic events, phenomena and processes.

Economic values are based on the concepts of «wealth», «money», «income,» as well as relatively more abstract categories such as «capitalism», «socialism», «individualism», «economic freedom», «equality», etc. Any society and social group have their own hierarchies of values. For some groups of the population, wealth can be valued as the highest good, for others it is «clear conscience». In some societies, private property can be regarded as a condition for the realization of the individual's economic and social freedom, and in others, it is treated as a social evil that generates social inequality and conflicts.

Ukrainian society has an underdeveloped market culture. A considerable part of the population has the egalitarian stereotypes and places all the responsibility for their well-being on the government, and above all, on the official system of social protection.

When teaching basic economic disciplines, it is important to emphasize that the market economy itself cannot be immoral, since it is only a mechanism of production and distribution that brings social benefits.

\section{Part 1. Economic culture development}

The author discusses the content, structure and functions of modern economic culture as an economic category as well as analyzes the relationship between economy and culture. The author also substantiates the importance of studying and formation of economic culture in the new socio-economic and political actualities of Ukraine. An objective of the system of higher education is believed to be the formation and development of professionals' economic competence in order to ensure their competitiveness and social mobility. The article deals with the role of organizational and economic culture factors in improving enterprise performance. The author analyzes their influence on the performance of the production personnel and managers, as well as on the formation of the internal environment of the enterprise. Economic culture is considered as a characteristic of economic relations and a regulator of economic behavior. Entrepreneurship and market-based labor motivation promote economic culture, which contributes to the development of the Ukrainian economy as socially oriented.

The changes that have been taking place in the educational system of Ukraine are aimed primarily at the personal development in a dynamically changing world. In line with this, the requirements for students' training also change. A modern educator should be not only a qualified specialist who has a good knowledge of the subject, but also be capable to perform a range of professional and socio-cultural activities, including creative self-development. 
One of the important objectives of higher education is formation of students' economic knowledge and economic competence to ensure their competitiveness and social mobility. Students' professional qualifications should be determined by their abilities to adapt to changing conditions and to develop and creatively use their economic knowledge.

Nowadays, people are looking for new meanings and new forms of development, while scientists are talking about a systemic crisis, which affects money, resources, ideologies, morals and culture, as a global challenge. A new era requires new rules. Ukraine, which is at the «civilization border» between the West and the East, Europe and Russia with their different economic and state structures, should become a comfortable, peaceful and socially harmonious country with its special place in the new world.

The aim of this article is to analyze the concept of economic culture and to attempt to determine its impact on the development of national economy in the conditions of current financial, economic and political crisis.

The political, economic, social and cultural transformations of the last decades have caused a serious transformation of the economic culture in Ukraine. There are distinct tendencies to individualize values, weaken paternalism, rationalize behavior, and increase individuals' responsibility for themselves, their families and the country. However, low productivity, slow economic reforms, impoverishment of the population, social stratification, unemployment and social insecurity, bring mass economic consciousness back to the Soviet period, when the state decided on everything. Given this, the study of the impact of economic culture on the country's economy is relevant, both in the theoretical and in practical aspects.

Economic culture is a basic category that reflects not only the quality of social relations during production, distribution and consumption of material goods, but also a qualitative characteristic and a measure of social development. Being an important economic development factor, economic culture requires special attention from economists, political scientists, sociologists and culturologists. There are philosophical, sociological and economic approaches that emphasize various aspects of economic culture. Economic culture has been studied by a number of Western (V. Zelizer, N. Bigard, P. Dimagio), Russian (I. Voitov, Y. Kuzminov, R. Ryvkina, O. Yanbolatova) and Ukrainian (T. Yefremenko, V. Pylypenko, E. Holovukha, Z. Halushka, and M. Simikin) economic sociologists who consider economic culture as the most important economic category.

Science does not have a single, generally accepted approach to understanding the content, structure and indicators of economic culture yet. In foreign and Ukrainian studies, the existing definitions of economic culture are based on different methodological approaches and represent various aspects of the phenomenon, which suggests its complexity and versatility. The most popular traditional approach reduces economic culture to economic consciousness in its 
stable forms and stereotypes [1, p. 55]. Under this approach, the key elements of economic consciousness include economic values, norms, orientations and traditions. Hence, the economic culture can be interpreted as a value-normative system, the values of which are shared by the majority of the society. At the same time, it should be noted that this approach does not make a holistic reflection of the nature of economic culture, in particular, its role in the sustained economic, cultural and social development of the country.

The economic approach is based on the analysis of economic relations and material resources and considers economic culture only as a factor in accelerating or slowing down socio-economic development. The philosophical approach, being a methodological basis, focuses on finding the most general laws of the development of nature, society and thinking, thus providing a fundamental abstract understanding of economic culture.

Analysis of economic culture in conjunction with the economic behavior of individuals and economic institutions provides a better understanding of the social mechanism of economic life development. The sociological approach is a constructive synthesis of the rational aspects of the above-mentioned approaches, which helps to assess the qualitative and quantitative characteristics of economic culture.

One can agree with Y. Kuzminov and T. Yefremenko, who treat economic culture as «a set of institutionalized activities» that ensure the adaptation of specific societies and groups to the economic conditions of their life. According to this approach, economic culture consists of behavioral stereotypes and economic knowledge viewed from the value and instrumental perspectives [6, p. 134].

Economic culture is one of the most important categories for describing the social mechanism of economic development. It can be defined as a system of values and incentives for economic activity, respect to any form of ownership and commercial success as a great social achievement, rejection of «equalization», creation and development of a positive social environment for entrepreneurship [8]. Thus, economic culture is a special area of culture associated with the reproduction of relations between people in the process of and for their economic activities. This is a kind of projection of the economy onto culture. However, culture itself, in turn, is projected onto the economy. These two parallel processes have a mutual impact on each other. As the objective conditions of life gradually, but purposefully form certain mental characteristics of people, the actual level of economy sets the objective cultural standards for the society, social groups and individuals [6, p. 126].

Economic culture has its own complex sociogenesis, which depends on a number of factors, from geographical to mental. Embodying moral, religious and aesthetic values, economic culture forms its own core - the national economic consciousness, which can be either constructive or destructive. 
An individual is always a carrier of culture. At the same time, economic culture manifests itself in institutions, technologies and products. It always acts as a qualitative characteristic of economic activity.

Economic culture includes the following main components: economic knowledge, economic thinking and economic orientations. In other words, economic culture is a combination of social norms and values that act as regulators of economic behavior and perform the function of a kind of social memory of economic development. Besides, economic culture is a set of standard economic behaviors.

Economic values are generally accepted ideas about the goals that an individual strives for in economic activity. They function in the form of an ideal, the basic principles of thinking and are the ideal criteria for assessing economic events, phenomena and processes.

Economic values are based on the concepts of "wealth», "money», «income,» as well as relatively more abstract categories such as «capitalism», «socialism», «individualism», «economic freedom», «equality» etc. Any society and social group have their own hierarchies of values. For some groups of the population, wealth can be valued as the highest good, for others it is «clear conscience». In some societies, private property can be regarded as a condition for the realization of the individual's economic and social freedom, and in others as a social evil that generates social inequality and conflicts.

Economic culture is a multidimensional phenomenon that consists of both rational and irrational components and is based on economic values and norms, economic stereotypes, ideas, concepts, beliefs, traditions, as well as people's attitudes towards the existing economic system as a whole, «rules of the game» and the principles of the relationship between the individual and economic institutions

Specific historical conditions influence people's economic behavior changing the values that shape it. Scientists identify at least three such elements, which are work ethic, scientific and professional knowledge, as well as the norms of people's behavior. Work ethic is about people's attitudes to work, which are contained in the norms and moral values of the society and embodied in cultural categories and ideas that are realized in labor [11, p. 172]. Although, from the standpoint of economic efficiency, the market economy is the best one, sociological surveys show that not all Ukrainians accept its norms and values (only 30-35\% of Ukrainians support free enterprise society). This can be explained by poor mass base of market ideology in Ukraine, which, as a rule, unites society around the ideas of economic efficiency, freedom and private property.

It can be argued that in Ukraine, work ethic is of a conservative nature. The mass economic consciousness of the Ukrainian society, on the one hand, reflects deinstitutialization in the country, and on the other, it aggravates the contradictions and deepens the gap between social and economic practices, 
since the functioning of both new and old socio-economic institutions in Ukraine brings about double economic norms. The duality of institutional rules (the old Soviet values have been supposedly rejected, whereas the new ones, which are democratic and market oriented, have not been adopted by the majority of the population yet) is manifested in people's ambivalent attitudes towards the institutional foundations of economic life.

The duality and contradiction of the social position has two aspects. Firstly, in the mass and individual consciousness, the mutually exclusive value and normative subsystems coexist as coordinated elements of single consciousness and attitude to socio-economic reality, rather than antagonists,

Secondly, contradictory value systems are characteristic of every large social group, rather than different social groups, whose rivalry could eventually lead to the establishment of a hierarchical system. And thirdly, ambivalence is manifested in the controversial combination of the democratic goals of social transformations and the totalitarian ways of achieving these democratic goals [3, p. 28].

In general, ambivalent mass economic consciousness is a product of political, economic and cultural transformations that have led Ukrainian society to social and economic instability. In the context of deinstitutialization, ambivalent consciousness is the norm. Culture, among other things, characterizes the quality and level of sociality, for it essentially turns a person into a social being.

Under socio-cultural transformations, professional knowledge becomes an important element of social economic culture. This can be explained by the fact that a socio-cultural transformation has economic causes, and, therefore, is accompanied by active material and technical transformations, which, in turn, requires in-depth professional retraining.

Thus, the idea of life-long education is of great importance during sociocultural transformations, when new technologies require constant development of employees' knowledge and skills. Economic reforms suggest that an individual acquires innovative economic knowledge. New knowledge, in turn, inevitably changes the entire economic culture.

And finally, the third element of economic culture, the norms of human behavior, also undergoes significant changes during the period of sociocultural transformations, for the changing norms change the traditional ideas about human behavior.

Thus, the economic culture of society, being a set of certain values that regulate and direct human behavior during the socio-cultural transformations, changes qualitatively, adapting to new historical realities.

Unlike culture, which preserves previous experience, social memory is connected with history; therefore the violent destruction of traditions «as the key elements of the mechanism of continuity and integrity of cultural space» creates a cultural vacuum $[6$, p. 130]. That is why during the fundamental social, economic and political reforms, it is necessary to be very careful with 
the cultural component of these transformations. Creation of a new economic culture is a very subtle and slow process that requires a strict distinction between the cause and effect.

Researchers of economic culture propose to distinguish three aspects of this complex social phenomenon: theoretical, practical and ethical. The theoretical aspect is based on the economic theory and the corresponding scientific concepts. The development of certain economic skills is the practical aspect, while the acquisition of a new value system adequate to a certain economic system is an ethical aspect of economic culture [1, p. 57].

Mass economic culture, being an important factor in economic renewal, needs a certain modification. As it has been already noted, the Ukrainian society has an underdeveloped market culture. A considerable part of the population has the egalitarian stereotypes and places all the responsibility for their well-being on the government, and above all, on the official system of social protection $[4$, p. 25].

Equally dysfunctional is the understanding of economic reforms in terms of administrative regulation of the economy, which inhibits economic and social modernization. Culture is an extremely stable phenomenon. The Soviet system of management existed not only institutionally, but also mentally. Even being critical of the past economic culture, people cannot change quickly because values and social behavioral norms are deeply rooted in their consciousness. As T. Yefremenko put it, the loss of traditions, values and norms of behavior that have not been compensated for by new norms and values, creates a «cultural vacuum» and turns the economic culture of society from the driving force of development into a socio-economic progress inhibitor [6, p. 138].

Modern economic culture of Ukraine suffers from uncertainty and inconsistency, which is caused by numerous changes in the official economic course of Ukraine, social instability, economic and financial crises. Economic reforms are associated with the development of new economic values and norms, which lead to self-regulation and economic culture renewal followed by the adaptation to a changing economic environment. Culture is relatively independent, and therefore, as it develops, it creates the ground for economic changes.

Considering the economic culture of the Ukrainian society, researchers distinguish its three levels: the society, the state and the individual. As for the first level, it is important to form a tolerant economic ideology in the public consciousness. Economic culture at the state level is the responsibility of the education system. The economic culture of the individual is reflected in their economic competence, economic activity, and in the application of economic knowledge in everyday life.

When analyzing the economic culture of modern Ukrainian society, it is necessary to consider the whole complex of economic culture components: organization and management culture, production culture, market culture, consumption culture, and financial culture. The indicators of economic 
culture include business and professional competence and the legal and ethical standards of economic activity.

The study of the economic culture of modern Ukrainian society can be helpful in determining the priorities of national development and in developing a socio-economic transformation strategy.

\section{Part 2. Formation of students' economic culture}

In order to promote economic development of the country, educational institutions should train skillful and economically cultured professionals. Therefore, the main objective of the higher education is the training of professionals of a new type, who are knowledgeable, innovative, creative, adaptive and good team workers.

Economic culture, as a part of humanitarian culture, has all the essential, features inherent in culture in general. Economic culture has a special place and performs specific functions in the culture system.

Usually, economic culture is defined as an organic unity of individuals' economic knowledge, beliefs and practical creative activity. It is difficult to make a clear differentiation between the functions of economic theory. Broadly, the main functions of economic culture include cognitive, applied and educational ones. The cognitive function helps individuals to familiarize themselves with economic theory and practice. This allows to consider economic culture as a reflection of economic life, as a way of understanding complex relationships and interactions in goods production, distribution, exchange and consumption, as well as the basis of individuals' worldview, which is made up of economic ideas and views.

The applied, or production, function of economic culture comes into play when individuals use economic knowledge to make competent economic decisions in their everyday / professional activities using their organizational skills and abilities.

Today, every technological decision has an economic aspect. Economic culture is the basis of any professional activity because it implies entrepreneurial and creative qualities, competence, professional skills, and responsibility.

We speak about the educational function of economic culture when knowledge turns into beliefs and then into actions.

Beliefs are essentially a fusion of the rational and emotional in knowledge assimilation.

An important component of economic culture is economic consciousness, i.e., the knowledge of the basic laws of the market economy, production efficiency, production restructuring, production relations as well as management system and management methods. Economic consciousness provides an understanding of the economic life of society, the transformation of employees into active and creative participants of the production process. In the conditions of economic reforms, the formation of professionals' economic consciousness becomes common and binding. 
The constituent of economic consciousness is economic thinking, which is the individual's ability to comprehend the phenomena of economic life based on the achievements of science and technology. It contributes to the individual's creative solution of economic problems and labor tasks. The economic culture of the individual, which is formed through training and education, is a set of the psychological and economic qualities that represent the normative model of the economic person and ensure his/her entry into the world of economy. Therefore, the economic culture of the individual is not just economic knowledge, financial literacy and relevant skills, but, above all, personal qualities, which enable a professional to operate in the economic space. In these conditions, the mission of economic education is the formation of the type of economic culture that would meet modern market requirements (Figure 1).

\begin{tabular}{|c|c|c|}
\hline \multicolumn{3}{|c|}{$\begin{array}{c}\text { Economic culture of society } \\
\text { (the system of economic values, the normative law of which is the economic } \\
\text { personality) }\end{array}$} \\
\hline \multicolumn{3}{|c|}{1} \\
\hline \multicolumn{3}{|c|}{$\begin{array}{l}\text { Intrapsychological system of the individual } \\
\text { (endopsychological manifestations) }\end{array}$} \\
\hline \multicolumn{3}{|c|}{ 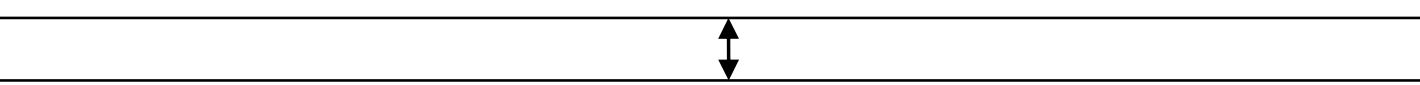 } \\
\hline \multicolumn{3}{|c|}{$\begin{array}{l}\text { Economic value representations of the individual, which internalize the economic } \\
\text { culture of society (economic values from the perspective of the normative } \\
\text { economic personality) }\end{array}$} \\
\hline \multicolumn{3}{|c|}{ 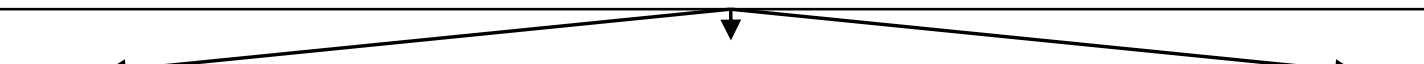 } \\
\hline $\begin{array}{l}\text { Cognitive component } \\
\text { (economic knowledge, } \\
\text { economic ideas, } \\
\text { economic information) } \\
\text { with the indicators of } \\
\text { the economic } \\
\text { personality disposition }\end{array}$ & $\begin{array}{l}\text { Affective component: } \\
\text { - practical emotions } \\
\text { (satisfaction with labor); } \\
\text { - emotions of glory } \\
\text { (need of self- } \\
\text { affirmation); } \\
\text { - pugnacious emotions } \\
\text { (excitement, risk); } \\
\text { - altruistic emotions; } \\
\text { - communicative } \\
\text { emotions, etc. with the } \\
\text { indicators of the } \\
\text { economic personality } \\
\text { disposition }\end{array}$ & $\begin{array}{l}\text { Conative component } \\
\text { (economic interest, } \\
\text { economic motives, } \\
\text { economic orientation) } \\
\text { with the indicators of } \\
\text { the economic } \\
\text { personality disposition }\end{array}$ \\
\hline \multicolumn{3}{|c|}{ I } \\
\hline Economic and ps & logical characteristics of $t$ & nomic personality \\
\hline
\end{tabular}

Figure 1. The structural model of personal economic culture 
Given that personal economic culture characterizes an individual of an economic type, the study of the market economy culture requires making a normative model of the respective economic personality.

The links between economic and moral cultures seem very important. Moreover, it can be argued that economic and moral cultures share the same goals, i.e., the formation of ideas, attitudes, principles and rules of conduct in line with the universal humanitarian values.

In fact, the goal of economic education is to develop students' personal qualities relevant to market relations.

To be competitive in the market economy, besides other qualities, individuals should be active, autonomous and responsible. Therefore, individuals should combine personal and economic interests, in other words, they have to satisfy other people's needs by satisfying their own needs. The universal human values stem from the conditions and values of the social environment.

Economic culture and, on its basis, economic thinking are developed by education, which teaches economic theories and forms ideas, attitudes, economic qualities and behaviors.

The core of individuals' economic culture is economic consciousness. Economic education, focused on the development of individuals' economic consciousness and thinking, necessitates the development of students':

- economic worldview;

- competence to assess economic processes and make correct economic decisions;

- competence to assess public policies;

- competence to make technical decisions in terms of their economic efficiency;

- competence to organize their work and life.

Most Ukrainian universities have a fairly clear system of economic education, which gives students knowledge of the main economic categories and concepts in their connection with the market economy, country's economic strategy and global economic problems.

This is achieved through the use of different students' works (tests, program-oriented and problem tasks, brain storming, business games, etc.).

Situational seminars involve decision-making with the analysis of specific situations, which develop students' analytical skills by means of reasoned defense of their positions in discussions.

Student business games create complex production situations, in which the players take up different roles and responsibilities and make collective decisions.

Such activities develop students' economic thinking making them critically assess the economic transformations of today and make optimal decisions in any economic situation. The modern educational standards of economic 
disciplines make it possible to expand students' system of economic views, concepts, assessments and conclusions, and to form a new type of thinking to fit the market economy.

It should be noted that economic changes modify people's psychology and moral values. Essentially, a new model of life is taking shape, based on new values and ideals: individualism, selfishness, uncertainty, passiveness, semicriminal activities, egotism and the primacy of material values.

Economic culture may be rather mobile in terms of changing knowledge to meet the requirements of a new economic system, unlike moral values, which remain unchanged.

When teaching basic economic disciplines, it is important to emphasize that the market economy itself cannot be immoral, since it is only a mechanism of production and distribution that brings social benefits. Market economy is based on competition and free markets. Competition stimulates labor productivity and free markets allow to avoid a shortage of goods, thus improving social well-being.

Under a market economy, people strive for profit, while relying on the generally accepted ethical norms, which allows to coordinate personal and public interests. The absence of such moral regulation leads to state regulation of the economy, i.e., non-ethically oriented market needs greater legal regulation, and vice versa.

What is certain, however, is that in conditions of economic freedom and competition, the importance of ethical regulation increases. The economyrelevant moral principles require that:

- the highest productivity and profits should be environment-friendly;

- competition should obey fair rules;

- goods distribution should not lead to the appearance of declassed population;

- technology should serve man, not vice versa.

The Ukrainian state educational standards establish general requirements for the content of comprehensive and vocational education. They list the disciplines that every student of any specialty should study.

Along with the obligatory disciplines, the basic university courses include elective subjects. Elective subjects have certain advantages over traditional subjects.

Firstly, a teacher has the opportunity to realize their professional and scientific potential developed through work and self-education. This implies the expansion of elective economic subjects, which contributes to the optimal development of students' professional competence.

Secondly, students' choice of elective subjects promotes a certain spiritual contact between a teacher and a student, which has a positive effect on the work of the both.

Thirdly, an in-depth study of a particular problem may turn into a powerful attraction towards the course being studied. 
To some extent, the recommended elective courses may include «Entrepreneurship and Business Culture», «Ethics of Entrepreneurship», «History of Economic Thought», «Securities Market», «Management», «Marketing», etc. The «Entrepreneurship and Business Culture» course is of special significance as it allows to study absolutely new phenomena for Ukraine, such as business and entrepreneurship, as well as gives basic skills in business organization (i.e., business planning, which is a prerequisite for successful entrepreneurship).This course highlights the ethical standards of entrepreneurship. Students should understand that a successful business includes entrepreneurs / businessmen and consumers / customers / buyers. The system of relations between them is a market, which, as it has been already noted, is largely regulated by ethical principles. A civilized market sets fairly stringent requirements for business entities. The moral qualities that businessmen should have are honesty (integrity, trustworthiness), nobility (dedication, loyalty, courage, generosity, etc.) and frugality (economical and expedient use of funds is contrasted with unneeded luxury and mismanagement).

In the absence of strict state control over economic activities, the listed moral norms become the most important regulators of business relations and competition. In countries with a developed market economy and democracy, the majority of the population understands that the richer the entrepreneurs, the higher taxes they will pay, which will be used for different social programs. Social inequality threatens wellbeing of many people, but it is better to be not rich under social inequality than to be poor as others under an egalitarian system.

A double degree as a form of economic education is quite popular in Ukraine as it allows to become an economist, manager, marketer or financier at the same time as a student completes his/her studies at a technical college. This undoubtedly expands the range of students' future professional activities, increases their general level of education and creates the opportunities for their career advancement or more efficient business.

In addition to traditional forms of education (as it is shown by our sociological surveys), student extracurricular work plays a special role in shaping their economic culture.

The rich content of elective courses creates prerequisites for the creation of interest clubs, scientific circles, round tables, trainings, and oral magazines around them. These can become a successful continuation of the classes.

Economic culture can be shaped only in conditions of continuous education. The continuous economic training has two aspects. On the one hand, economic elements should be present in all disciplines: humanitarian, general scientific or special. On the other hand, economic education should be provided throughout the entire period of university education.

This should obviously be presented in a single program of economic education for the entire period of university study. The following 
recommendations can be helpful in developing an economic education program:

1. Economic departments should consider the specialization of the university and schools and use the material of general scientific and technical disciplines as well as the achievements of the relevant industries. The departments should provide advice to students and $\mathrm{PhD}$ students in analyzing the economic aspects of the scientific problems that are the subjects of their essays, term papers, dissertations, master's thesis, contest works and projects.

2. The departments of general scientific and technical disciplines should focus on strengthening the economic aspect of lectures, seminars, workshops and research works.

3. Economic departments should, in turn, hold joint meetings with special departments to discuss the economic aspects of scientific problems as well as the achievements of the Ukrainian and foreign science and technology.

4. University Academic Councils should discuss the progress of students' economic training and the ways of its improvement at their meetings.

5. It is advisable to hold methodological seminars at the university to improve the economic culture of all teaching staff.

The following topics may be recommended for including in the economicsoriented technological course:

- the role of the Ukrainian scientists in the development of science and technology;

- the unity of technical, economic, social and organizational tasks;

- the place and role of the specific scientific discipline in accelerating scientific and technological progress;

- the increasing social role of the technical intellectuals, the aesthetics of technological creativity, responsibility for the preservation of the environment;

- the moral and aesthetic aspects in the teaching of the specific discipline;

- the formation of an active citizen position: the need for labor, the observance of the rules of educational and production discipline, behavioral norms and ethics.

The continuity of economic education is also achieved through the individual work with students, which allows them to develop practical skills, diligence, efficiency, enterprise, organization, economy, and respect to state property as well as to develop the skills in the scientific organization of work and time management.

All the above discussed classroom and extracurricular work is aimed at improving education and easing the formation of economic culture, which undoubtedly increases the professional mobility and social security of individuals in a market economy. It seems that the main focus of this work should be on the development of the individuals' need for intellectual activity in the presence of multiple opinions and the need for a critical assessment of ideas, concepts and theories. 
The organization of economic education largely depends on a lecturer of economic disciplines and his/her ability to organize the educational process effectively. At lectures it is important to attract students' attention to key problems of economic development, while at the seminars, it is necessary to involve all students in the educational process.

As practice has shown, the most effective is dialogical teaching. Free exchange of opinions and the atmosphere of ease greatly speeds up students' development of economic knowledge and stimulates the formation of their consistent beliefs. Group discussions of different issues of the economy may be also helpful.

Thus, a university lecturer has a large choice of means and methods of influencing students in order to shape their economic culture.

A huge role in education is played by the personality of the teacher. If a teacher is socially active, principled and civic minded and if his/her judgments are bold and new, if he/she is a carrier of economic culture, then the students who interact with him/her more easily choose their life positions and achieve self-realization.

A study conducted by economic psychologists confirmed that the behavior of the «economic person» cannot be explained only by simple laws of profit gaining, rational calculations and/or rational choice. The researchers argue that economic consciousness includes:

- economic emotions and feelings (satisfaction from the results and the process of labor, the desire to be recognized and respected, to overcome the danger, to feel the excitement because of risking as well as altruistic or selfish intentions);

- the perceptual sphere of economic behavior (money perception, attitudes towards things, goods, services, consumer psychology, advertising, selling methods);

- ideas of how the economy functions; a creation of a subjective economic idea;

- the ability of an individual or a social group to reflect and comprehend economic phenomena, to understand their nature, assimilate and correlate economic concepts, categories and theories with economic laws;

- motivational components of economic consciousness (economic norms, interests, actions, etc.) [7].

Considering the economic essence of the market relations person (human worker, human owner), it should be emphasized that their very professional activity requires constant creative and innovative mood and deeply influences their personal and world-view self-determination. "An entrepreneur is an economic entity whose function in the economy as a business system is to create (and implement) new combinations of production factors, and who himself is an active element of this process. An entrepreneur is an initiator of economic innovations in social life» [2]. According to the encyclopedic sociological dictionary, the entrepreneur is 
«the leading agent of the market process who initiates a business for the production of goods and services with the aim of making a profit» [2], and entrepreneurial activity is «the active introduction of innovations and new technologies, the creative search for «new combinations», the mass production of new products and the provision of new services» [2]. Entrepreneurial activity is a component of social activity, where the latter is «a characteristic of the life of a social agent (individual, group), that reflects the conscious orientation of their activity and behavior to change the social environment, conditions and/or institutions according to the agent's urgent needs, interests, goals and/or ideals» [3, p. 9]. The professional qualities of a market environment person, who is of an entrepreneurial personality, thus require the presence in the phenomenological structure of their consciousness of a constant willingness for active transformative, innovative and creative activities. Studying the worldview, philosophy and morality of modern entrepreneurs, it is necessary to turn to the social-philosophical analysis of their interests, needs and hobbies in order to find out how an economic person forms his/her living environment within the marketeconomic space. In this aspect, it is important to note that individuals' purely economic, commercial interests and needs are necessarily complemented by their personally significant, spiritually oriented and individually satisfying interests. «In the conditions of economic development adequate to the new economy, particular importance is given not only to the qualitative characteristics of a human worker (such as competence, i.e., knowledge, skills, experience, qualifications, continuous education, self-education, intellect, innovation, creativity), but also to the qualitative characteristics of a human personality. These are decency, honesty, responsibility, sociability, trust, collectivism, the ability to cooperate, etc.» $[9$, p. 11].

Thus, the objectives and mechanisms of the development of economic culture as an economic activity factor constantly change under the influence of environment. In the final analysis, economic culture allows to improve the company efficiency and win the competition.

\section{Conclusions}

The interests and needs of a modern entrepreneur cover the whole range of social interactions from purely professional activities to daily routine work and leisure time. The moral motivation of an individual has several important components, which, besides the economic needs, include such spiritual and moral needs as the needs for self-expression, self-realization, social recognition, social contacts and public evaluation of their work. These motives stem from the natural human needs for respect, high self-esteem and social prestige, etc.

The personal qualities that make an individual competitive at the labor market can be formed in the national system of education and culture 
development. It is the system of education that can convince young people and the whole society of the necessity to be guided by certain moral, cognitive, ethical and aesthetic, etc. principles in their professional and personal self-realization.

The strategic mission of higher education is not only to give students the relevant professional knowledge and skills, but also to develop students' economic culture and promote their professional and personal self-realization.

The economic culture of society, which is a synthesis of the material and spiritual, shapes economic behavior that combines the material, economic and spiritual aspects of human life; it is the result of creative activity of people in the process of production, exchange, distribution and consumption of material and spiritual goods.

The economic education largely depends on lecturers of economic disciplines and their ability to effectively organize the educational process.

In addition to traditional forms of education, student extracurricular work plays a special role in shaping their economic culture.

When teaching basic economic disciplines, it is important to emphasize that the market economy itself cannot be immoral, since it is only a mechanism of production and distribution that brings social benefits.

The economic culture of society, which is a synthesis of the material and spiritual, forms the economic behavior that combines the material, economic and spiritual aspects of human life; it is the result of creative activity of people in the process of production, exchange, distribution and consumption of material and spiritual goods.

\section{References:}

1. Voitov, I. V. (2009). Ekonomicheskaya kultura v sisteme priroda + chelovecheskoe obschestvo [Economic culture in the nature+human society system]. XXI Mezhdunarodnaya studencheskaya konferentsiya [XXI International student conference]. Moscow: ROAT. (in Russian)

2. Beregulyak U. I. (2019). Formuvannia kultury maibutnogo pratsivnyka u protsesi profesiinoi pidgotovki [Formation of the future worker's culture in the professional training's process]. U. I. Beregulyak. Retrieved from: http://archive.nbuv.gov.ua/portal/ soc_gum/VChdpu/ped/2019_88 (accessed 08.10.2019).

3. Halushka Z. I. (2008). Faktory formuvannia ekonomichnoi kultury ukrainskoho suspilstva [Factors of formation of economic culture of the Ukrainian society]. Ekonomichna teoriia, no. 1, pp. 22-29.

4. Deyneka O. S. (2000). Ekonomicheskaya psikhologiya: ucheb. pos. SPb.: SanktPeterburgskiy universitet [Economic psychology]. (in Russian)

5. Dimaggio P. (1994). Culture and Economy. The Handbook of Economic Sociology / Princeton, pp. 27-57.

6. Yefremenko, T. (2006). Ekonomichna kultura naselennya suchasnoyi Ukrayiny [Economic culteure of the population of modern Ukraine]. Sotsiologiya: teoriya, metody, marketyng [Sociology: Theory, Methods, Marketing], no. 3, pp. 123-141.

7. Maistruk, I. M. (2007). Ekonomichna kultura za umov rynkovykh realii v Ukrayini [Economic culture in market economy in Ukraine]. Retrieved from: http://www.ukrsocium.org.Ua/Arhiv/Stati/3.2007/77-90.pdf 
8. Ovsiankina L. A. (2003). Moral v systemi ekonomichnoi zhyttiediialnosti liudyny ta suspilstva (sotsialno-filosofskyi aspekt) [Morality in the system of economic life of man and society (socio-philosophical aspect)] (PhD Thesis), Kyiv.

9. Siryi Ye. V. (2005). Kultura pidpryyemnytstva v konteksti iogo sotsialnoi roli [The culture of entrepreneurship in the context of its social role]. Ukrainskiisotsium. Sotsiologiia. Ekonomika. Polityka, № 2-3, pp. 100-108.

10. Savytska N. L. (2010). Evoliutsiia modeli liudyny v ekonomichnii teorii [Evolution of the human model in economic theory]. Visnyk Khmelnytskoho natsionalnoho universytetu. T. 2, pp. 137-140.

11. Spitsyna A. Ye. (2015). Suchasnii stan rozvytku vyshchoi ekonomichnoi osvity v Ukraini [The current state of development of higher economic education in Ukraine] // Sotsialno-ekonomichni problemy prostorovogo rozvytku: monografiya; zazag. red. V. Duchmala, T. Nestorenko. Berdyansk: VydavetsTkachuk O.V., pp. 166-174.

12. Suryak, A. V. (2000). Vplyv ekonomichnoyi kultury na motyvatsiyu pratsi v umovakh rynkovoyi transformatsiyi [Effects of economic culture on labor motivation in conditions of market transformation]. Oplata pratsi: problemy teoriyi ta praktyky [Wages and Salary: Problems of Theory and Practice]. Lutsk: Vezha, pp. 54-57. 